\title{
Small for Gestational Age Babies: Morbidity and Immediate Outcome in a Tertiary Care Hospital - A Prospective Study
}

\author{
ARJUN CHANDRA DEY ${ }^{1}$, FARID UDDIN AHMED ${ }^{2}$, MD ABDUL MANNAN ${ }^{3}$, LAXMI SAHA ${ }^{4}$, CHOWDHURY $^{2}$. \\ CHIRANJIB BARUA ${ }^{5}$, CHOWDHURY B MAHMOOD 6
}

\begin{abstract}
Background: Birth weight is the single most important determinant of survival and subsequent growth and development of the newborn. In Bangladesh there is high prevalence of low birth weight ( $L B W$ ) babies and most of them are small for gestational age. The study was conducted to identify the proportion and category of the small for gestational age babies and determination of the short-term outcome with the aim to the reduction of neonatal mortality and morbidity by problem-wise intervention.

Methods: This cross sectional study was conducted in the Neonatal Unit of Chittagong Medical College Hospital, Chittagong between December 2000 and July 2001. Neonates admitted into this unit weighing less than $10^{\text {th }}$ percentile of weight for gestational age were included. On admission the weight was taken and gestational age was calculated using last menstrual period and Ballard score. The infants were monitored daily till discharge or death.

Result: A total of 200 SGA babies were included in the study. Among 200 cases 114 were male and 86 were female. All cases were included within 24 hours of age. The anthropometric analysis of the SGA babies showed more than $80 \%$ of the SGA babies were normal in length whereas $19.5 \%$ fell below $10^{\text {th }}$ percentile of normal. Seventy three percent of SGA babies were asymmetrically (disproportionate) and $27 \%$ of babies were symmetrically (proportionate) growth retarded. The main problems associated with the SGA babies were perinatal asphyxia (65.5\%), sepsis (54\%), jaundice (42.0\%), hypothermia (31\%), apnea (29\%), hypoglycemia (25\%), and bleeding manifestations (9\%). Asymmetrical SGA babies were at higher risk of infection and jaundice. Present study revealed the mortality of SGA babies were $17 \%$ and mortality was significantly higher among the neonates from low socio-economic status and having very low birth weight, hypothermia, apnea, sepsis, bleeding manifestations, and polycythemia.

Conclusion: Findings in this study could be important in identifying the areas requiring attention to improve perinatal care in order to prevent SGA babies and also to manage the problems associated with them.
\end{abstract}

\section{Introduction}

Birth weight is generally used as a yardstick of maturity and is an important determinant of child survival and development ${ }^{1,2}$. Low birth weight is the single most important determinant of the survival and subsequent

1. Department of Neonatology, BSMMU, Shahbag, Dhaka

2. Associate Professor, Department of Paediatrics, Chittagong Medical College Hospital, Chittagong

3. Associate Professor, Department of Neonatology, BSMMU, Shahbag, Dhaka

4. Medical Officer, Sadar Hospital, Feni

5. Consultant, Paediatrics, Chittagong Medical College Hospital, Chittagong

6. Principal and Professor of Paediatrics (Ex) Chittagong Medical College Hospital, Chittagong

Correspondence: Dr. Arjun Chandra Dey growth and development of the newborn. Bangladesh perinatal survey in 1983 showed the proportion of LBW in Bangladesh to be very high, being highest in the rural areas (45\%) and IUGR contributing almost $75 \%$ of those. In another study in Bangladesh it was reported that the prevalence of LBW was about $27 \%$ amongst which about $84 \%$ were small for gestational age and the rests were preterm ${ }^{3}$. In both the cases it was obvious that the low birth weight babies comprise almost one third of total birth of which around 80\% are small for gestational age. Extrapolating the findings of the studies, around 4 million births take place in Bangladesh in a year. Most of these babies are obviously small for gestational age $\mathrm{a}^{4}$. 
Nearly four decades ago it became apparent that a significant number of low birth weight newborns classified as premature were born at term. The small size of these infants could only be explained by retarded prenatal growth ${ }^{5,6}$. The recognition of fetal growth retardation as a new syndrome was soon followed by studies demonstrating that mortality rates were much higher in these infants than in normally grown newborns of similar gestational age, although lower than in premature infants. It was also found that infants suffering from fetal growth retardation were more susceptible to certain types of neonatal complications ${ }^{7,8}$. This information greatly stimulated research in the area, thus contributing to the progress of high-risk obstetrics and neonatal care.

Most of the risk factors of IUGR like maternal malnutrition, frequent child birth, illiteracy, heavy work, inadequate antenatal check-up, etc exist in such an extensive manner which is unlikely to be changed drammatically in the near future. If the problems of SGA babies are identified in a good setting, a proper message could be constructed for mothers, TBAs and also health personnels so that timely necessary steps can be taken to avoid problems in the rural areas without any modern facilities.

\section{Methods}

It was a hospital based cross-sectional study conducted between December 2000 and July 2001 in the Neonatal Unit of Chittagong Medical College Hospital, Chittagong. Neonates admitted into this unit weighing less than $10^{\text {th }}$ percentile of weight for gestational age were included. On admission the nude weight of the babies was taken by the investigators using National Nutrition Council (NNC) Bar Scale having $20 \mathrm{gm}$ graduation. Gestational age was calculated using last menstrual period and Ballard score. Ponderal index was calculated for all babies. The infants were monitored daily till discharge or death.

\section{Results}

A total of 200 SGA babies were included in the study. Among 200 cases 114 were male and 86 were female. All cases were included within 24 hours of age. Most of the SGA babies were belonging to poor (45\%) or middle class families (49\%) and only a few (6\%) were from upper class families. Cases were delivered either in maternity, in clinic or in hospital. Only $14 \%$ were delivered at home. Among the 200 babies $84 \%$ babies were results of single pregnancy and $16 \%$ were of multiple pregnancies (Table-I). The anthropometric analysis of the SGA babies showed more than $80.5 \%$ of the SGA babies were normal in length whereas $19.5 \%$ fell below $10^{\text {th }}$ percentile of normal. In $52 \%$ of the cases birth weight fell between 1500-1999 gm and in only $3 \%$ cases birth weight less than $1500 \mathrm{gm}$. Around $90 \%$ cases were having normal occipitofrontal circumference and rest of them were having microcephaly.

Proportionality of the growth of SGA babies was assessed on the basis of Ponderal index. Seventy three percent of babies were asymmetrical (disproportionate) and $27 \%$ of babies were symmetrical (proportionate) SGA.

Feeding pattern of babies was analyzed. In only $21 \%$ cases exclusive breast-feeding was possible and in $60 \%$ cases breast was associated with artificial feeding mainly due to lack of or poor communication with the mother who were placed away from the neonatal ward. In $18 \%$ cases, babies were fully dependent on parenteral nutrition for more than 1 week.

Asphyxia was diagnosed on the basis of APGAR score at one minute of delivery (Table 2). Around $70 \%$ of the babies were asphyxiated and $10 \%$ were cases of severe perinatal asphyxia. Hypothermia was another common problem affecting $31 \%$ of the cases. About two third of these cases had only one episode. Around $13 \%$ cases had multiple $(>3)$ episodes.

Twenty nine percent of the cases had apneic spells. About 38\% of apnea occurred on the first day of life, but good number of cases with apnea were found throughout the first week of life. A total of 86 (43\%) cases developed jaundice of which $69.3 \%$ were physiological and $31.7 \%$ were pathological as evident by clinical and laboratory findings including analysis of direct and indirect serum bilirubin. Jaundice appeared within 4 days of life in all cases.

Nine percent of cases developed bleeding manifestations. All of them occurred in first week of life. Six cases were clinically suspected of IVH, 5 of them were confirmed by ultrasonography of brain and cerebral ventricles. Sepsis was detected in 54.0\% cases. Most cases of sepsis were early onset type. Lethargy (100\%) and reluctant to feed (94.4\%) were found to be the most consistent symptoms of sepsis. Raised IT ratio (74.07\%), leucocytosis (50.93\%) or leucopenia (14.81\%) and positive C-reactive protein 
(57.41\%) were used as supportive investigation in favour of neonatal sepsis (Table-III).

Episodes of hypoglycemia in the SGA babies were detected and relation to birth was seen. Twenty five percent cases developed hypoglycemia; most of them were inversely related to birth weight. All the symptomatic cases found were in the birth weight group of less than $2000 \mathrm{gm}$. Polycythemia was found in $11 \%$ cases. Polycythemia was inversely related to the birth weight and all cases of polycythemia were having birth weight less than $2000 \mathrm{gm}$.

Among the 200 cases $40 \%$ of were required hospitalization for 6 to 10 days. Only 26\% of cases were possible to be discharged within 5 days. Overall mortality was $17 \%$, which had an inverse relationship with the birth weight. Less than $1500 \mathrm{gm}$ birth weight group had shown the highest mortality (66.67\%) whereas more than $1999 \mathrm{gm}$ birth weight group had the lowest mortality (6.67\%).
Symmetrical and asymmetrical SGA babies were analyzed for the relative risk of development of different clinical problems. Among the clinical features physiological jaundice and neonatal sepsis were significantly associated with asymmetrical SGA. Other clinical problems didn't show any significant difference in frequency in the symmetrical and asymmetrical SGA babies. Relation of mortality with different general characteristics and clinical problems were analyzed. Factors found to be significantly related to higher risk of mortality were birth weight, low socioeconomic condition, vaginal delivery, APGAR score at one minute, lack of breast feeding, hypothermia, apnea, sepsis, bleeding manifestations, IVH, and polycythemia. However place of delivery, symmetry or asymmetry of SGA type, jaundice, meconium aspiration syndrome, hypoglycemia were found not to affect the mortality of SGA babies significantly (Table-IV).

Table-I

Characteristics of SGA babies $(n=200)$

\begin{tabular}{|c|c|c|c|c|c|}
\hline \multicolumn{3}{|c|}{ Characteristics } & \multirow{2}{*}{$\begin{array}{c}\text { Number } \\
176\end{array}$} & \multirow{2}{*}{$\begin{array}{c}\text { Percentage } \\
88\end{array}$} & \multirow{2}{*}{$\begin{array}{c}\text { Remarks } \\
\text { Range 0.5-24 }\end{array}$} \\
\hline & & $<6$ & & & \\
\hline \multirow{2}{*}{\multicolumn{2}{|c|}{ Age (hrs) }} & $7-12$ & 20 & 10 & mean $3.24 \pm 1.38$ \\
\hline & & $13-24$ & 04 & 2 & \\
\hline \multirow[t]{2}{*}{ Sex } & Male & & 114 & 57 & \\
\hline & Female & & 86 & 43 & \\
\hline \multirow{3}{*}{\multicolumn{2}{|c|}{ Socio-economic status }} & Poor & 90 & 45 & \\
\hline & & Middle & 98 & 49 & \\
\hline & & Rich & 12 & 6 & \\
\hline \multirow{4}{*}{\multicolumn{2}{|c|}{ Place of delivery }} & Home & 28 & 14 & \\
\hline & & Maternity & 38 & 19 & \\
\hline & & Clinic & 32 & 16 & \\
\hline & & Hospital & 102 & 51 & \\
\hline \multirow{3}{*}{\multicolumn{2}{|c|}{ Mode of delivery }} & Vaginal & 134 & 67 & \\
\hline & & LSCS & 54 & 27 & \\
\hline & & Instrumental & 12 & 6 & \\
\hline \multirow{2}{*}{\multicolumn{2}{|c|}{ Type of pregnancy }} & Single & 168 & 84 & \\
\hline & & Multiple & 32 & 16 & \\
\hline
\end{tabular}


Table-II

Grade of asphyxia (according to APGAR score-at $1 \mathrm{~min}$

$$
n=200
$$

\begin{tabular}{lcc}
\hline Grade & Number & Percentage \\
\hline Normal & 30 & 15 \\
Mild & 58 & 29 \\
Moderate & 61 & 30.5 \\
Severe & 20 & 10 \\
Not known & 31 & 15.5 \\
\hline
\end{tabular}

Table-III

Neonatal sepsis $(n=108)$

\begin{tabular}{lcc}
\hline Features(Clinical/laboratory) & Number & Percentage \\
\hline Lethargy & 108 & 100 \\
Reluctance to feed & 102 & 94.4 \\
Jaundice & 35 & 32.4 \\
Abdominal distention & 44 & 40.7 \\
Convulsion & 40 & 37.0 \\
Sclerema & 26 & 24.0 \\
Leucocytosis & 55 & 50.1 \\
Leucopenia & 16 & 14.8 \\
Raised IT ratio & 80 & 74.1 \\
Positive CRP & 62 & 57.4 \\
\hline
\end{tabular}

Table - IV

Relative risks of problems of symmetrical \& asymmetrical SGA babies

\begin{tabular}{|c|c|c|c|c|c|c|}
\hline Problems & & $\begin{array}{c}\text { Symmetrical } \\
\text { Number } \\
(\%)\end{array}$ & $\begin{array}{l}\text { Asymmetrical } \\
\text { Number } \\
(\%)\end{array}$ & $\begin{array}{c}\text { Statistical } \\
\text { significance } \\
\text { (P value) }\end{array}$ & $\begin{array}{c}\text { Relative } \\
\text { risk }\end{array}$ & $\begin{array}{c}\text { Confidence } \\
\text { interval }\end{array}$ \\
\hline \multirow[t]{2}{*}{ Hypothermia } & Yes & $16(25.8)$ & $46(74.2)$ & NS & 0.94 & $0.57<R R<1.55$ \\
\hline & No & $38(27.5)$ & $100(72.5)$ & & & \\
\hline \multirow[t]{2}{*}{ Apnea } & Yes & $16(27.6)$ & $42(72.4)$ & NS & 1.03 & $0.63<\mathrm{RR}<1.70$ \\
\hline & No & $38(26.8)$ & 104(73.2) & & & \\
\hline Physiological & Yes & $20(41.7)$ & $28(58.3)$ & $<0.01$ & 2.92 & $1.29<\mathrm{RR}<6.58$ \\
\hline Jaundice & No & 06(14.3) & $36(85.7)$ & & & \\
\hline \multirow[t]{2}{*}{ Bleeding } & Yes & 02(11.1) & 16(88.9) & NS & 0.39 & $0.10<\mathrm{RR}<1.47$ \\
\hline & No & $52(28.5)$ & $130(71.4)$ & & & \\
\hline \multirow[t]{2}{*}{ Neonatal sepsis } & Yes & $20(18.5)$ & $88(81.5)$ & $<0.01$ & 0.50 & $0.31<\mathrm{RR}<0.81$ \\
\hline & No & $34(30.0)$ & $58(63.0)$ & & & \\
\hline Meconium & Yes & $04(28.6)$ & $10(71.4)$ & NS & 1.06 & $0.45<R R<2.52$ \\
\hline Asp Syndrome & No & $50(26.9)$ & 136(73.1) & & & \\
\hline \multirow[t]{2}{*}{ Hypoglycemia } & Yes & $12(24.0)$ & $38(76.0)$ & NS & 0.86 & $0.49<R R<1.49$ \\
\hline & No & $42(28.0)$ & 108(72.0) & & & \\
\hline \multirow[t]{2}{*}{ Polycythemia } & Yes & $46(25.6)$ & $134(74.4)$ & NS & 0.64 & $0.35<R R<1.15$ \\
\hline & No & 08 (80.0) & $12(60.0)$ & & & \\
\hline \multirow[t]{2}{*}{ Out come } & Death & 6(18.6) & $28(82.4)$ & NS & 0.49 & $0.27<\mathrm{RR}<1.23$ \\
\hline & Survival & $52(28.9)$ & 118(71.1) & & & \\
\hline
\end{tabular}

NS - Not Significant 
Table -V

Different characteristics and clinical problems versus outcome

\begin{tabular}{|c|c|c|c|c|c|}
\hline $\begin{array}{l}\text { Characteristics } \\
\text { \& problems }\end{array}$ & & $\begin{array}{c}\text { Survival } \\
\text { Number(\%) }\end{array}$ & $\begin{array}{c}\text { Death } \\
\text { Number (\%) }\end{array}$ & $\begin{array}{c}\text { Total } \\
\text { Number (\%) }\end{array}$ & $\begin{array}{c}\mathrm{P} \\
\text { value }\end{array}$ \\
\hline Birth weight (Gm) & $\begin{array}{l}1000-1499 \\
1500-1999 \\
\geq 2000\end{array}$ & $\begin{array}{c}02(33.3) \\
80(76 . .9) \\
84(93.3)\end{array}$ & $\begin{array}{l}04(66.7) \\
24(23.1) \\
06(6.7)\end{array}$ & $\begin{array}{c}06(3) \\
104(52) \\
90(45)\end{array}$ & $<0.01$ \\
\hline Sex & $\begin{array}{l}\text { Male } \\
\text { Female }\end{array}$ & $\begin{array}{l}102(89.5) \\
64(74.4)\end{array}$ & $\begin{array}{l}12(10.5) \\
22(25.6)\end{array}$ & $\begin{array}{l}114(57) \\
86(43)\end{array}$ & $<0.05$ \\
\hline $\begin{array}{l}\text { Socio-economic } \\
\text { status }\end{array}$ & $\begin{array}{l}\text { Pool } \\
\text { Middle } \\
\text { Rich }\end{array}$ & $\begin{array}{l}64(71.1) \\
92(93.9) \\
10(83.3)\end{array}$ & $\begin{array}{l}26(28.9) \\
06(6.1) \\
02(16.7)\end{array}$ & $\begin{array}{c}90(45) \\
98(49) \\
12(6)\end{array}$ & 0.01 \\
\hline Place of delivery & $\begin{array}{l}\text { Home } \\
\text { Maternity } \\
\text { Clinic } \\
\text { Hospital }\end{array}$ & $\begin{array}{l}18(64.3) \\
30(79.0) \\
26(81.2) \\
92(91.2)\end{array}$ & $\begin{array}{c}10(35.7) \\
08(21.0) \\
06(18.8) \\
10(9.8)\end{array}$ & $\begin{array}{c}28(14) \\
38(19) \\
32(16) \\
102(51)\end{array}$ & NS \\
\hline Mode of delivery & $\begin{array}{l}\text { Vaginal } \\
\text { LSCS } \\
\text { Instrumental }\end{array}$ & $\begin{array}{c}110(82.1) \\
50(92.6) \\
06(500)\end{array}$ & $\begin{array}{c}24(17.9) \\
04(7.4) \\
06(50.0)\end{array}$ & $\begin{array}{c}134(67) \\
54(27) \\
12(6)\end{array}$ & $<0.01$ \\
\hline Asphyxia & $\begin{array}{l}\text { Mild } \\
\text { Moderate } \\
\text { Severe }\end{array}$ & $\begin{array}{l}66(89.2) \\
94(87.7) \\
06(30.0)\end{array}$ & $\begin{array}{l}08(10.8 \mathrm{~J} \\
12(11.3) \\
14(70.0)\end{array}$ & $\begin{array}{c}74(37) \\
106(53) \\
20(10)\end{array}$ & $<0.01$ \\
\hline Ponderalindex & $\begin{array}{l}\text { Symmetrical } \\
\text { Asymmetrical }\end{array}$ & $\begin{array}{l}48(88.9) \\
118(80.8)\end{array}$ & $\begin{array}{l}06(11.1) \\
28(19.2)\end{array}$ & $\begin{array}{l}54(27) \\
146(73)\end{array}$ & NS \\
\hline Feeding & $\begin{array}{l}\text { Breastmilk } \\
\text { Artificial } \\
\text { I/V infusion } \\
\text { Partial B. feeding }\end{array}$ & $\begin{array}{c}42(25.3) \\
02(1.2) \\
22(61.2) \\
100(83.7)\end{array}$ & $\begin{array}{c}- \\
- \\
14(38.8) \\
20(16.6)\end{array}$ & $\begin{array}{c}42(21) \\
02(1) \\
36(18) \\
120(60)\end{array}$ & $<0.01$ \\
\hline Hypothermia & $\begin{array}{l}\text { Yes } \\
\text { No }\end{array}$ & $\begin{array}{c}38(61.3) \\
128(92.8)\end{array}$ & $\begin{array}{c}24(38.7) \\
107.2)\end{array}$ & $\begin{array}{c}62(31) \\
138(69)\end{array}$ & $<0.01$ \\
\hline Apnea & $\begin{array}{l}\text { Yes } \\
\text { No }\end{array}$ & $\begin{array}{c}32(55.2) \\
134(94.4)\end{array}$ & $\begin{array}{c}26(44.8) \\
08(5.6)\end{array}$ & $\begin{array}{l}58(29) \\
142(71)\end{array}$ & $<0.01$ \\
\hline Sepsis & $\begin{array}{l}\text { Yes } \\
\text { No }\end{array}$ & $\begin{array}{l}74(68.5) \\
92(55.4)\end{array}$ & $\begin{array}{c}34(31.5) \\
-\end{array}$ & $\begin{array}{l}108(54) \\
92(46)\end{array}$ & $<0.01$ \\
\hline Jaundice & $\begin{array}{l}\text { Yes } \\
\text { No }\end{array}$ & $\begin{array}{c}78(90.7) \\
88(77.2)\end{array}$ & $\begin{array}{c}08(9.3) \\
26(22.8)\end{array}$ & $\begin{array}{c}86(43) \\
114(57)\end{array}$ & NS \\
\hline Bleeding & $\begin{array}{l}\text { Yes } \\
\text { No }\end{array}$ & $\begin{array}{c}06(33.3) \\
160(88.0)\end{array}$ & $\begin{array}{l}12(66.7) \\
22(12,0)\end{array}$ & $\begin{array}{c}18(9) \\
182(91)\end{array}$ & $<0.01$ \\
\hline MAS & $\begin{array}{l}\text { Yes } \\
\text { No }\end{array}$ & $\begin{array}{c}08(57.2) \\
158(85.0)\end{array}$ & $\begin{array}{l}06(42.8) \\
28(15.0)\end{array}$ & $\begin{array}{c}14(7) \\
186(93)\end{array}$ & NS \\
\hline $\mathrm{IVH}$ & $\begin{array}{l}\text { Yes } \\
\text { No }\end{array}$ & $\begin{array}{c}02(16.7) \\
164(75.3)\end{array}$ & $\begin{array}{l}10(83.3) \\
24(24.7)\end{array}$ & $\begin{array}{c}12(6) \\
188(94)\end{array}$ & $<0.01$ \\
\hline Hypoglycemia & $\begin{array}{l}\text { Yes } \\
\text { No }\end{array}$ & $\begin{array}{c}38(76.0) \\
128(84.3)\end{array}$ & $\begin{array}{l}12(24.0) \\
22(15.7)\end{array}$ & $\begin{array}{c}50(25) \\
150(75)\end{array}$ & NS \\
\hline Polycythemia & $\begin{array}{l}\text { Yes } \\
\text { No }\end{array}$ & $\begin{array}{c}12(60.0) \\
154(85.6)\end{array}$ & $\begin{array}{c}08(40.0) \\
26(14.4)\end{array}$ & $\begin{array}{c}20(10) \\
180(90)\end{array}$ & $<0.05$ \\
\hline
\end{tabular}




\section{Discussion}

Low birth weight babies comprise about $27 \%$ of total birth in Bangladesh amongst which about $84 \%$ are SGA babies. Therefore a large proportion of newborn babies admitted in the neonatal units are SGA babies $^{4}$.

Most of the cases attended hospital within 6 hours of birth. Male female ratio among cases was 57: 43 which is little higher than the normal sex distribution of the general population of the country (Census- 2001) probably indicating preference of the parents to seeking health care for male child.

Anthropometric analysis of the babies revealed some important variables. Around $20 \%$ of the cases attained supine length, which was below $10^{\text {th }}$ percentile of $\mathrm{NCHS}$. All of these cases are term SGA as because only full-term babies were included in the sample so that problems exclusively related to prematurely couldn't affect the objective of the study. OFC measurement shows about $12 \%$ of the babies were born with microcephaly, which might play a vital role on the future development of these babies.

Ponderal index of the 200 SGA babies of present study showed that $73 \%$ were asymmetrical and $27 \%$ of them were symmetrical, which is quite consistent with the study conducted previously by Ahmed et. $\mathrm{al}^{4}$. They showed that proportion of asymmetrical SGA babies were $84 \%$. Higher proportion of asymmetrical SGA babies signifies the onset of growth retardation in the later weeks of intrauterine life. However the portion of asymmetrical SGA declined to some extent, which probably dictates the trend of improvement in the antenatal care.

In growth retarded neonates asphyxia is 5 to 10 times more common than in their fully-grown peers ${ }^{9}$. In this study asphyxia of different grades affected around $70 \%$ cases which is the most frequent problem found to be associated with SGA babies. SGA infants are highly susceptible to the development of hypothermia because they have a reduced capacity to retain and generate body heat. The quantity of brown adipose tissue is markedly reduced in small for date infants ${ }^{10}$. Hypothermia complicated about $31 \%$ cases and two third of these cases had only one episode. About 13\% cases had multiple ( $>3$ ) episodes. Hypothermia was mostly associated with severely growth-retarded babies. Among the 200 SGA infants of the present study $29 \%$ of cases developed apnoea, which is quite high. But most of these cases were as a complication of periantal asphyxia. Some were related to septicemia. Jaundice developed in $43 \%$ of cases among which $41.7 \%$ were pathological (direct hyperbilirubinemia) mainly as a manifestation of neonatal sepsis.

Bleeding, though not a recognized complication of SGA were found in $9 \%$ cases. All these cases were diagnosed as haemorrhagic disease of the newborn (HDN). IVH the most serious type of HDN was found $3 \%$ of cases.

SGA infants are very much prone to infection owing to many factors particularly depressed immunity ${ }^{11,12}$. Sepsis was found to be associated with $54 \%$ of cases, which is important causal factor of mortality and longer hospital stay.

In a recent study in India ${ }^{13}$, it is shown that overall incidence of hypoglycemia was $25.2 \%$. The present study showed that twenty five percent of the SGA infants developed hypoglycemia. Polycythemia was found in $18 \%$ cases in this study. This is consistent with acceptable prevalence rate of polycythemia in SGA infants ${ }^{14}$ which is considerably higher than $5 \%$ in fully grown neonates ${ }^{15}$. Development of problems in the SGA babies were analyzed in relation to symmetry and asymmetry pattern of growth retardation. Only neonatal sepsis and physiological jaundice were found to be significantly more associated with asymmetrical SGA babies. Other problems have failed to show any significant difference between two groups of SGA infants. Mortality was also not significantly affected by the pattern of intrauterine growth retardation. This result has shown mixed impression considering the result of the study conducted by Cuttini et.al. ${ }^{16}$. Their study showed a consistently higher risk of death in the symmetrical SGA babies during the neonatal period. Morbidity defined by the asphyxia, respiratory distress and neonatal infection were higher in those symmetrically small babies.

Overall mortality was found $17 \%$, which is not so high especially considering the national picture of neonatal mortality ${ }^{17}$ and spectrum of problems in these SGA babies. This data probably reflects the result of special care delivered to the newborn babies in a well-equipped separate neonatal unit in the study place. Very low birth weight, poor socio-economic condition, APGAR score at one minute, lack of breast feeding, hypothermia, apnea, sepsis, bleeding manifestations and polycythemia were found to be significantly 
associated with higher mortality whereas place of delivery, intrauterine growth pattern and hypoglycemia did not show any significant relationship to the higher mortality.

\section{Conclusion}

Present study concluded that the greater proportion of SGA babies is contributed by asymmetrical pattern of intrauterine growth retardation. The main problems need to be anticipated in the newborn are perinatal asphyxia, hypothermia, apnea, jaundice, sepsis and hypoglycemia. Improvement of perinatal care is required in order to prevent the birth of SGA babies and also to manage the problems associated with them.

\section{References}

1. Ebrahim GJ. Low birth weight baby. In: Practical mother and child health in developing countries, MacMillan Press Ltd. 1982 (Reprinted).

2. WHO, The incidence of low birth weight, A critical review of available information, World Health Statistics Quarterly, 1980, Vol: 33 No-3, pp-197224.

3. Ahmed FU, Rahman ME, Perveen R. Utilization of trained traditional birth attendants (TBA) in rural Bangladesh. JCMCTA 1996; 6: 23-26.

4. Ahmed FU, Alam MB, Bhuiyan SN. Birth weight specific neonatal mortality and morbidity in a birth cohort. Bangladesh J Child Health. 1999; 23: 1-5.

5. Douglus JWB. Some factors associated with prematurity. J Obstet Gynaecol Br Cwlth 1950; 57: $143-70$.

6. Scott KE, Usher R. Fetal malnutrition: its incidence causes and effects. Am J Obstet Gynaecol 1966; 94: 951-63.

7. Van den Berg B, Yerushalmy J. The relationship of intrauterine growth of infants of low birth weight to mortality, morbidity and congenital anomalies. J Pedriatr 1966; 69: 531-45.
8. Lin C, Evans MI. Intrauterine growth retardation. Pathophysiology and clinical management. New York: McGraw-Hill. 1984; p. 15-51.

9. McDonald HM, Mulligan JC, Allen AC, Taylor P. Neonatal asphyxia. I. Relationship of obstetric and neonatal complications in neonatal mortality in 405 consecutive deliveries. J Pediatr 1980; 96: 898-902.

10. Aheme W, Hull D. Brown adipose tissue and heat production in the newborn infant. J Path Bact 1966; 911: 223-34.

11. Saha K, Kaur P, Srivastava G, Chaudhury DS. A six months follow-up study of growth, morbidity and functional immunity in low birth weight neonates with special reference to intrauterine growth retardation in small-for-gestational age infants. J Trop Paediatr 1983; 29: 278-82.

12. Ferguson AC. Prolong impairment of cellular immunity in children with intrauterine growth retardation. J Paediatr 1978; 93: 52-56.

13. Batt MA, Kumar P, Bhansali A, Majumdar $S$, Narang A. Hypoglycemia in small for gestational age babies. Indian J Pediatr 2000; 67: 423-27.

14. Hakanson DO, Oh W. Hyperviscosity in the small-for-gestational age infant. Biol Neonate 1980; 37: 109-12.

15. Wirth FH, Goldberg KE, Lubchenco LP. Neonatal hyperviscosity. Incicence and effect of partial plasma transfusion. Pediatr Res 1975; 19: 372(abstr).

16. Cuttini M, Cortinovis I, Bossi A, de-Vonderweid $U$. Proportionality of small for gestational age babies as a predictor of neonatal mortality and morbidity. Paediatr Perinat Epidemiol. 1991; 5: 56-63.

17. Bangladesh demographic and health survey. 1999-2000, preliminary report. 